\title{
PENGARUH HARGA, KUALITAS PRODUK DAN GAYA HIDUP TERHADAP WILLINGNESS TO PAY (WTP) SEMANGKA ORGANIK
}

\author{
Lydia Indra Setung ${ }^{1}$, Yoseph Yakob Da Rato ${ }^{2}$ \\ ${ }^{1,2}$ Program Studi Agribisnis, Fakultas Pertanian, Universitas Nusa Nipa \\ e-mail : ${ }^{1}$ setung17@gmail.com ${ }_{2}^{2}$ joseph9d@gmail.com
}

\begin{abstract}
ABSTRAK
Pola konsumsi pangan masyarakat semakin bergeser menuju perubahan pola hidup sehat. Munculnya kesadaran akan bahaya kandungan zat kimia membuat masyarakat lebih selektif dalam memilih suatu produk untuk dikonsumsinya. salah satu alternatif pangan yang merujuk pada pola hidup sehat adalah semangka organik. Harga semangka organik yang relatif mahal menimbulkan daya tarik tersendiri bagi konsumen kelas tertentu. Penelitian ini bertujuan untuk mengetahui pengaruh harga produk, kualitas produk, dan gaya hidup terhadap willingness to pay (WTP) semangka organik. Analisis data yang digunakan adalah analisis deskriptif, dan Analisis Regresi Linier Berganda. Penelitian dilaksanakan di Kebun Praktek Fakultas Pertanian Universitas Nusa NipaIndonesia selama 2 bulan yaitu dari tanggal 01 Oktober - 04 Desember 2020. Teknik pengambilan sampel menggunakan Accidental Sampling dengan jumlah responden sebanyak 38 orang. Hasil penelitian menunjukkan variabel gaya hidup berpengaruh signifikan secara parsial terhadap willingness to pay semangka organik. Sementara itu, seluruh variabel (Harga produk, Kualitas Produk, dan Gaya Hidup) berpengaruh signifikan secara simultan (bersama-sama) terhadap willingness to pay semangka organik di Kebun Fakultas Pertanian Universitas Nusa Nipa Indonesia.
\end{abstract}

Kata kunci: Harga Produk, Kualitas Produk, Gaya Hidup, Willingness to pay, Semangka Organik.

\section{ABSTRACT}

People's food consumption patterns are increasingly shifting towards healthy lifestyle changes. The emergence of awareness of the dangers of chemical substances makes people more selective in choosing a product for their consumption. one food alternative that refers to a healthy lifestyle is organic watermelon. The price of organic watermelon is relatively expensive to create its own attraction for consumers of a certain class. This study aims to find out the influence of product prices, product quality, and lifestyle on willingness to pay (WTP) organic watermelon. The data analysis used is descriptive analysis, and Multiple Linear Regression Analysis. The research was conducted in the Practice Garden of the Faculty of Agriculture, University of Nusa NipaIndonesia for 2 months from 01 October - 04 December 2020. Sampling techniques using Accidental Sampling with the number of respondents as many as 38 people. The results showed lifestyle variables had a partially significant effect on willingness to pay organic watermelon. Meanwhile, all variables (Product price, Product Quality, and Lifestyle) have a significant effect simultaneously (together) on willingness to pay organically in the Garden of the Faculty of Agriculture, University of Nusa Nipa Indonesia.

Keywords : Product Price, Quality Products, Lifestyle, Willingness to pay, Organic Watermelon. 


\section{PENDAHULUAN}

Indonesia merupakan negara yang kaya akan hasil pertanian. Negara ini diuntungkan karena dikaruniai oleh kondisi alam yang mendukung, hamparan lahan yang luas, keragaman hayati yang melimpah, serta beriklim tropis dimana sinar matahari terjadi sepanjang tahun sehingga bisa menanam sepanjang tahun realita sumberdaya alam seperti ini sewajarnya mampu membangkitkan Indonesia menjadi negara yang makmur, tercukupi kebutuhan pangan seluruh warganya. Hal tersebut memberikan peluang bagi sebagian besar masyarakat Indonesia untuk melakukan kegiatan usaha di bidang pertanian (Warsani, 2013).

Pembangunan sektor pertanian tidak hanya tanaman perkebunan tetapi juga tanaman hortikultura. Tanaman hortikultura terbagi menjadi tiga jenis tanaman yaitu tanaman buah-buahan, tanaman sayuran dan tanaman bunga atau hias. Manfaat produk hortikultura bagi manusia antara lain sebagai sumber pangan dan gizi, pendapatan rumah tangga, pendapatan nasional, dan penyangga kelestarian alam bagi lingkungan (Arief, 1990). Salah satu tanaman hortikultur yang memiliki potensi pengembangan yang cukup besar merupakan tanaman semangka.

Tanaman semangka merupakan salah satu tanaman buah semusim yang berumur kurang dari setahun, bersifat rumpun, menyebar dan berbatang lunak. Semangka (Citrullus Lanatus) hanya dapat menghasilkan buah sekali dalam satu musim tanam, kemudian tanaman akan mengering dan mati.

Pola konsumsi pangan masyarakat Indonesia semakin bergeser menuju perubahan pola hidup yang lebih memperhatikan lingkungan. Munculnya kesadaran akan bahaya kandungan zat kimia membuat masyarakat lebih selektif dalam memilih suatu produk untuk produk pangan yang dikonsumsinya.

Pemerintah Indonesia telah mencanangkan program go organik sejak tahun 2010 lalu untuk mempercepat terwujudnya pembangunan agribisnis berwawasan lingkungan (ecoagribusiness). Program ini berorientasi pada pasar yakni berusaha memenuhi keinginan pasar, dimulai dari bawah ke atas. Salah satu kegiatannya adalah memasyarakatkan pertanian organik kepada konsumen, petani, pelaku pasar serta masyarakat luas (Widiastuti,2004).

Mengkonsumsi produk organik mengubah persepsi masyarakat Indonesia untuk melakukan gaya hidup organik. Mengkonsumsi produk pangan organik tidak hanya sebagai pemenuhan kebutuhan dasar saja tetapi juga terdapat pertimbangan lainnya seperti tingkat keamanaan (food safety atributes) dan kandungan gizi (nutritional atributes) dari produk makanan yang akan dikonsumsi serta ramah lingkungan (eco-labelling atributs).

Perkembangan permintaan akan produk organik banyak disebabkan oleh meningkatnya kesadaran masyarakat untuk mengkonsumsi produk pangan yang rendah residu bahan kimia sebagai bagian dari kecenderungan gaya hidup sehat dan kembali ke alam. Persepsi konsumen tentang produk tersebut sangat bervariasi, oleh karena itu para pemasar harus memerhatikan kebutuhan dan selera konsumen demi menghadapi persaingan, karena saat ini kekuatan pasar ada di tangan pembeli, pemasar harus meningkatkan kualitas produknya agar menjadi produk yang berkualitas 
dan baik sehingga dapat memenuhi permintaan dan kebutuhan konsumen.

Salah satu yang dilakukan oleh masyarakat dalam menerapkan gaya hidup organik yaitu dimulai dengan mengkonsumsi semangka organik. Semangka organik merupakan salah satu produk pertanian organik yang sekarang ini mulai dikembangkan oleh petani dengan menghasilkan berbagai varietas semangka organik. Jika dibandingkan dari produknya, semangka organik dan anorganik sangat berbeda.

Harga penjualan semangka organik relatif lebih mahal dibandingkan dengan semangka non organik. Semangka organik ditanam dengan aplikasi pupuk organik dan ramah terhadap lingkungan sedangkan semangka anorganik dibudidayakan dengan menggunakan pupuk kimia dan pestisida (Ratih dkk, 2013). Harga semangka organik yang relatif mahal tersebut menimbulkan daya tarik tersendiri bagi konsumen kelas tertentu yang kemudian mengubah pola konsumsi semangkanya dari semangka yang dibudidayakan secara anorganik ke semangka organik, sehingga daya tarik dan popularitas semangka yang diusahakan secara anorganik berkurang bagi konsumen kelas tertentu. Penjualan semangka organik pun masih dikatakan terbatas karena hanya tersedia di tempat-tempat tertentu.

$$
\text { Pola hidup masyarakat }
$$

Kabupaten Sikka, dewasa ini telah mengarah ke pola hidup sehat. Yohanes (2005) menjelaskan pola hidup masyarakat di Sikka banyak yang mengkonsumsi makanan berserat. Tidak sedikit mengkonsumsi makanan berserat dan pangan organik menjadi salah satu menu makanan pilihan dengan berbagai alternatif konsumsi tertentu termasuk mengkonsumsi semangka organik. Kebun Praktek Fakultas Pertanian Universitas Nusa Nipa Indonesia merupakan lokasi praktek bagi Mahasiswa Fakultas Pertanian. Kebun Praktek ini berlokasi di Jalan Litbang, Kelurahan Kota Uneng, Kecamatan Alok, Kabupaten Sikka. Lahan tersebut digunakan untuk melakukan budidaya tanaman pangan dan hortikultura yang bergerak dalam bidang pertanian untuk mengembangkan berbagai jenis komoditas. Salah satunya adalah komoditi tanaman semangka organik yang menjadi pilihan untuk di kembangkan.

Berdasarkan latar belakang tersebut terhadap responden yang terbatas, menunjukkan bahwa konsumen masih memiliki persepsi produk organik sebagai produk yang mahal, sehingga perlu membahas seberapa daya beli/sumber dana atau willingness to pay (WTP) konsumen terhadap semangka organik. Willingness to pay (WTP) digunakan sebagai metode untuk mengetahui nilai maksimum yang bersedia dibayarkan oleh konsumen dari peningkatan kualitas sebuah produk.

\section{METODOLOGI PENELITIAN}

Penelitian dilaksanakan di Kebun Praktek Fakultas Pertanian Universitas Nusa Nipa Indonesia, Kabupaten Sikka, dari Tanggal 1 Oktober - 4 Desember 2020.

Analisis data adalah pengolahan data yang didapat dengan menggunakan rumus atau dengan aturan-aturan yang ada sesuai dengan pendekatan penelitian. Data yang diperoleh melalui kuesioner yang telah diisi oleh responden kemudian diolah dan dianalisa menggunakan teknik pengolahan data untuk menghasilkan 
suatu kesimpulan atas masalah yang diteliti.

\section{Analisis Deskriptif}

Analisis deskriptif dalam penelitian ini meliputi: Gambaran umum lokasi penelitian, dan Karakteristik Responden Berdasarkan Usia, Jenis kelamin, pekerjaan, tingkat pendidikan, dan pendapatan yang berpedoman pada kuisioner.

\section{Analisis Regresi Linier Berganda}

Tujuan penelitian, dianalisis menggunakan analisis Regresi Linier Berganda untuk melihat variabel yang mempengaruhi willingness to pay (WTP) semangka organik. Regresi linier bergandaadalah persamaan regresi yang melibatkan dua atau lebih variabel dalam analisanya.Tujuannya adalah untuk menghitung parameterparameter estimasi untuk melihatapakah variabel bebas mampu menjelaskan variabel terikat, sedangkan variabelvariabel yang mempengaruhi adalah variabel bebas. Model ini memperlihatkan hubungan variabel bebas (independent variabel) dengan variabel terikat (dependent variabel), digunakan untuk melihat harga produk, kualitas produk, dan gaya hidup terhadap willingness to pay semangka organik.

\author{
Untuk \\ mengidentifikasi \\ variabel dependen dan variabel \\ independen digunakan model analisis \\ inferensial, yaitu analisis Regresi Linier \\ Berganda yang dinyatakan dalam \\ bentuk fungsi sebagai berikut: \\ $\mathrm{Y}=\mathrm{f}\left(\mathrm{X}_{1}, \mathrm{X}_{2}, \mathrm{X}_{3},\right)$ \\ $\mathrm{Y}=\mathrm{b}_{0}+\mathrm{b}_{1} \mathrm{X}_{1}+\mathrm{b}_{2} \mathrm{X}_{2}+\mathrm{b}_{3} \mathrm{X}_{3}+\mathrm{e}$ \\ Dimana: \\ $\mathrm{X}_{1}=$ Harga Produk \\ $\mathrm{X}_{2}=$ Kualitas Produk \\ $\mathrm{X}_{3}=$ Gaya Hidup \\ $\mathrm{b}_{0}=$ Konstanta \\ $b_{1}, b_{2}, \ldots . . b_{3}=$ Parameter yang akan \\ diestimasi.
}

Regresi Linier Berganda diolah dengan menggunakan aplikasi SPSS yang merupakan sebuah program komputer statistik yang berfungsi untuk membantu dalam memproses data-data statistik secara tepat dan cepat. Hasilyang didapatkan adalah berbagai output yang dikehendaki oleh para pengambil keputusan.

\section{III.HASIL DAN PEMBAHASAN}

Data yang diperoleh merupakan data sampel yang berhasil dikumpulkan melalui teknik accidental sampling. Hasil data dalam bentuk skala ordinal kemudian dianalisis menggunakan analisis regresi berganda. Berikut hasil data faktor-faktor yang mempengaruhi willingness to pay semangka organik.

Tabel 1. Hasil Analisis Regresi Linear Berganda

\begin{tabular}{|c|c|c|c|c|c|c|}
\hline \multicolumn{7}{|c|}{ Coefficients $^{\mathrm{a}}$} \\
\hline & & \multicolumn{2}{|c|}{$\begin{array}{l}\text { Unstandardized } \\
\text { Coefficients }\end{array}$} & \multirow{2}{*}{$\begin{array}{l}\text { Standardized } \\
\text { Coefficients } \\
\text { Beta }\end{array}$} & & \\
\hline \multicolumn{2}{|c|}{ Model } & $\mathrm{B}$ & Std. Error & & $\mathrm{T}$ & Sig. \\
\hline 1 & (Constant) & 1,277 & 3,028 & & 0,422 & 0,676 \\
\hline & Harga Produk & $-0,006$ & 0,138 & $-0,007$ & $-0,043$ & 0,966 \\
\hline & Kualitas Produk & 0,181 & 0,136 & 0,220 & 1,333 & 0,191 \\
\hline & Gaya Hidup & 0,472 & 0,157 & 0,482 & 3,003 & 0,005 \\
\hline
\end{tabular}

Sumber: Output SPSS 25, 2021 
Dari hasil perhitungan pada Tabel 1, dapat dibuat persamaan regresi linear berganda untuk penelitian ini sebagai berikut :

$$
\begin{aligned}
& \mathrm{Y}=1,277-0.006 \mathrm{x}_{1}+0.181 \mathrm{x}_{2}+ \\
& 0.472 \mathrm{x}_{3}+\mathrm{e} \\
& \text { Dimana: } \\
& \mathrm{Y} \quad=\text { Willingness to pay }(\mathrm{WTP}) \\
& \mathrm{A} \quad=\text { konstanta } \\
& \mathrm{b} 1 \quad=\text { KoefisienregresiuntukX1 } \\
& \mathrm{b} 2 \quad=\text { KoefisienregresiuntukX2 } \\
& \mathrm{b} 3 \quad=\text { KoefisienregresiuntukX3 } \\
& \mathrm{X} 1 \quad=\text { Harga Produk } \\
& \mathrm{X} 2 \quad=\text { Kualitas Produk } \\
& \mathrm{X} 3 \quad=\text { Gaya Hidup } \\
& \mathrm{E} \quad=\text { NilaiResidu }
\end{aligned}
$$

Koefisien regresi $\mathrm{X}_{1}$ (harga produk) sebesar -0,006 yang berarti bahwa jikaX ${ }_{1}$ (harga produk) naik sebesar satu satuan, maka Y (willingness to pay) akan mengalami penurunan sebesar 0,006 satuan atau 6\% dengan asumsi bahwa variabel independen lainnya dianggap konstan. Dalam hal ini, harga yang berlaku terhadap semangka organik dianggap tidak dapat berdiri sendiri mempengaruhi willingness to pay (WTP). Hal ini sejalan dengan teori ekonomi dimana untuk konsumen cenderung ingin memperoleh hasil yang sebesar- besarnya dengan biaya yang serendah-rendahnya.

Koefisien regresi $\mathrm{X}_{2}$ (kualitas produk) sebesar 0,181 yang berarti bahwa jika $\mathrm{X}_{2}$ (kualitas produk) naik sebesar satu satuan, maka Y (willingness to pay) akan mengalami peningkatan sebesar 0,181 satuan atau $18,1 \%$ dengan asumsi bahwa variabel independen lainnya dianggap konstan. Pada variabel kualitas produk dengan indikator atribut produk dianggap tidak berpengaruh nyata terhadap willingness to pay (WTP) yang didapatkan, hal ini karena atribut produk tidak dapat dianggap mewakili kesediaan membayar konsumen saja, dengan kata lain kesanggupan konsumen untuk mengkonsumsi pangan sehat tidak didasarkan pada aspek kualitas produk yang ditunjukkan pada atribut produk saja, dalam hal ini, pengaruh yang diberikan belum cukup signifikan terhadap willingness to pay (WTP).

Koefisien regresi $X_{3}$ (gaya hidup) sebesar 0,472 yang berarti bahwa jika $\mathrm{X}_{3}$ mengalami peningkatan sebesar satu satuan, maka Y (willingness to pay) akan mengalami peningkatan sebesar 0,472 satuan atau $47,2 \%$ dengan asumsi variabel independen lainnya dianggap konstan.

Berdasarkan hasil tersebut, dapat dikatakan bahwa variabel $\mathrm{X}_{3}$ (gaya hidup) memiliki pengaruh yang dominan diantara seluruh variabel independen yang digunakan dalam penelitian ini karena mendapatkan hasil paling tinggi yaitu sebesar 0,472 atau $47,2 \%$. Gaya hidup sangat dipengaruhi oleh lingkungan konsumen baik dari segi pendapatan, usia, serta tingkat pendidikan maupun dalam mempengaruhi perilaku konsumen untuk membangun sikap kesadaran terhadap pola hidup sehatnya.

\section{Uji Korelasi Ganda(R)}

Uji ini digunakan untuk mengetahui hubungan antara variabel independen (harga produk,kualitas produk, dan gaya hidup) terhadap variabel dependen (willingness to pay) secara serentak. Koefisien ini menunjukkan seberapa besar hubungan yang terjadi antara variabel independen (harga produk, kualitas produk, dan gaya hidup) secara serentak terhadap variabel dependen (willingness to pay). Nilai R berkisar antara 0 sampai 1, nilai semakin mendekati 1 berartihubungan 
yang terjadi semakin kuat, sebaliknya nilai semakin mendekati 0 maka hubungan yang terjadi semakin lemah.

Sugiyono (2007) pedoman untuk memberikan interpretasi koefisien korelasi sebagai berikut:

$$
\begin{array}{lll}
0,00-0,199 & =\text { sangat rendah } \\
0,20- & 0,399 & =\text { rendah } \\
0,40- & 0,599 & =\text { sedang } \\
0,60- & 0,799 & =\text { kuat } \\
0,80- & 1,000 & =\text { sangat kuat }
\end{array}
$$

Dari hasil analisis regresi, dapat dilihat pada output model summary bahwa nilai $\mathrm{R}$ pada penelitian ini sebesar 0,615 yang berarti hubungan antara variabel independen (harga produk, kualitas produk, dan gaya hidup) secara serentak terhadap variabel dependen (willingness to pay) kuat.

\section{Uji Koefisien Determinasi $\left(\boldsymbol{R}^{2}\right)$}

Uji determinasi dalam regresi linear berganda digunakan untuk mengetahui persentase sumbangan pengaruh variabel independen (harga produk, kualitas produk, dan gaya hidup) secara serentak terhadap variabel dependen (willingness to pay). Koefisien ini menunjukkan seberapa besar persentase variasi variabel independen yang digunakan dalam model mampu dijelaskan variasi variabel dependen. Hasil analisis determinasi R Square faktor-faktor yang memengaruhi willingness to pay semangka organik di Kebun Praktek Fakultas Pertanian Universitas Nusa Nipa Indonesia.

.Tabel 2. Hasil Analisis Determinasi R Square.

\begin{tabular}{lccccc}
\hline \multicolumn{5}{c}{ Model Summary $^{\mathbf{b}}$} \\
\hline Model & $\mathrm{R}$ & $\mathrm{R}$ Square & $\begin{array}{c}\text { Adjusted R } \\
\text { Square }\end{array}$ & $\begin{array}{c}\text { Std. Error of the } \\
\text { Estimate }\end{array}$ \\
\hline 1 & $0,615^{\text {a }}$ & 0,378 & 0,323 & 1,364 \\
\hline \multicolumn{5}{l}{ a. Predictors: (Constant), Harga Produk, Kualitas Produk, Gaya Hidup, } \\
\hline \multicolumn{5}{l}{ b. Dependent Variable: Willingness to pay } \\
Sumber: Output SPSS 25 For, 2021
\end{tabular}

Berdasarkan Tabel 2 pengaruh serempak variabel harga, kualitas produk, dan gaya hidup terhadap willingness to pay diperoleh angka $\mathrm{R}^{2}$ (R Square) sebesar 0,378 atau (37,8\%). Hal ini menunjukkan bahwa presentase sumbangan pengaruh variabel independen (harga produk, kualitas produk, dan gaya hidup) terhadap variabel dependen (willingness to pay) sebesar $37,8 \%$. Sedangkan sisanya sebesar $62,2 \%$ dipengaruhi atau dijelaskan oleh variabel lain yang tidak dimasukkan dalam model penelitian ini.

Adjusted R Square adalah nilai $\mathrm{R}$ Square yang telah disesuaikan, nilai ini selalu lebih kecil dari R Square dan angka ini bisa memiliki harga negatif. Menurut Santoso (2001) bahwa untuk regresi dengan lebih dari dua variabel bebas digunakan Adjusted $\mathrm{R}^{2}$ sebagai koefisien determinasi.

Standard Error of the Estimate adalah suatu ukuran banyaknya kesalahan model regresi dalam memprediksikan nilai Y. Dari hasil regresi didapat nilai sebesar 1,364. Jika standard error of the estimate kurang dari standar deviasi $\mathrm{Y}$, maka model regresi semakin baik dalam memprediksi nilai Y. Model yang digunakan ini tergolong model baik. 


\section{IV.KESIMPULAN}

Berdasarkan data hasil uji simultan (uji F), menunjukkan nilai

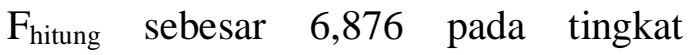
signifikansi 0,001 . Hasil yang diperoleh pada $\mathrm{F}_{\text {Tabel }}$ adalah sebesar 2,87. $\mathrm{F}_{\text {Tabel }}$ diperoleh pada tingkat signifikan dengan derajat kebebasan 0.025. Karena $F_{\text {hitung }}>F_{\text {Tabel }}(6,876>2,87)$ dan tingkat signifikansi< tingkat probabilitas $(0,001<0,25)$. Hal ini berarti bahwa harga produk, kualitas produk, dan gaya hidup secara bersama-sama atau secara simultan berpengaruh signifikan terhadap willingness to pay (WTP) pada responden semangka organik di Kebun Praktek Fakultas Pertanian Universitas Nusa Nipa Indonesia.

\section{DAFTAR PUSTAKA}

Adiningsih, S. 2010. Waspada Gizi Balita Anda. Jakarta: PT Elex Media Komputindo.

Anonimous. 2012. Manfaat Buah Semangka. http://manfaat dan kandungan. Blogspot.com.

Anonimous. 2013. Manfaat Buah Semangka untuk Kesehatan. Kanisius. Yogyakarta.

Alimuddin. 2013. Analisis Faktor-faktor Yang Mempengaruhi Permintaan Kendaraan Bermotor Roda Dua Di Kota Makasar. Jurnal Ilmiah Ilmu Ekonomi: Fakultas Ekonomi dan Bisnis UNHAS.

Aslam Anwar, M. 2016. Tingkat Preferensi Dan Kepuasan Konsumen Terhadap Beras Di Sulawesi Selatan. Skripsi Sosial Ekonomi Pertanian Universitas Hasanuddin Makassar.

Duljapar, K., dan R. N. Setyowati. 2000. Petunjuk Bertanam Semangka Sistem Turus. Penebar
Swadaya. Jakarta.

Damayanti, M.N. 2009. Kajian Keberhasilan Pelaksanaan Kemitraan dalam Meningkatkan Pendapatan Antara Petani Semangka di Kabupaten Kebumen Jawa Tengah Dengan CV Biromandiri. Skripsi. Fakultas Pertanian. Institut Pertanian Bogor. Bogor.

Grace Laumahina dan Njo Anastasia, 2014, Kesediaan untuk Membayar pada Green Residential, FINESTA vol. 2 no. 1 page $82-86$, Universitas Kristen Petra.

Ildrakasih, N. 2013. Faktor-Faktor Yang Mempengaruhi Keputusan Konsumen Dalam Membeli Beras Organik. Skripsi Program Studi Agribisnis Fakultas Pertanian Universitas Sumatera Utara,Medan.

Kotler, Philip.,Keller, Kevin L. (2013). Manajemen Pemasaran, Jilid Kedua, Jakarta: Erlangga.

Melisa K. 2014. Produk Pertanian Organik Indonesia Tinjauan Atas Preferensi Konsumen Indonesia Terhadap Produk Pertanian Organik Local. Jurnal Studi Manajemen 8 (2): 171-173.

Rukmana, R. 2006. Budidaya Semangka Hibrida. Kanisius. Yogyakarta.

Rina, R. 2011. Peranan Bauran Pemasaran (Marketing Mix) terhadap Peningkatan Penjualan (Sebuah Kajian terhadap Bisnis Restoran). Jurnal Kompetensi Teknik Vol 2.

Ratih Pravita, dkk. 2013. Persepsi Konsumen terhadap Beras Organik dan Anorganik di Tolo Satvika Boga Sanur Denpasar. Jurnal 
Ilmiah PS Agribisnis Fakultas Pertanian, Universitas Udayana. EJurnal Agribisnisdan Agrowisata, ISSN;2301-6523 Vol.2, No.2.

Thio, Sienny.2012. Persepsi Konsumen Terhadap Makanan Organik di Surabaya. Program Manajemen Perhotelan, Fakultas Ekonomi, Universitas Kristen Pertra. Jurnal Penelitian Universitas Petra.
Widiastuti, S., (2004, April 23). Go Organik 2010. Berita Pertanian Organik. Retrieved February 28, 2009, from http://www.go-organik 2010/berita pertanian/91887/ organik.

Wigati, S. 2011. Perilaku Konsumen dalam Perspektif Ekonomi Islam. Jurnal Ilmiah Fakultas Syariah IAIN Sunan Ampel Surabaya. 